\title{
Business Approach Using Ecoefficiency Concept in Enhancing Competitive Advantage Based on Green Product Efforts
}

\author{
Mochammad Ilyas Junjunan" ${ }^{\# 1}$ Hamidah $^{* 2}$ \\ ${ }^{\#}$ Fakultas Ekonomi dan Bisnis Universitas Airlangga \\ Surabaya, Indonesia \\ lilyasmochammad30egmail.com \\ 2hamidahrudy@yahoo.com
}

\begin{abstract}
This study aims to determine the business approach by using the concept of ecoefficiency in increasing competitive advantage based on the efforts of green product. The amount of industrial increase is proportional to the amount of increased pollution generated from industrial production processes [1]. We intend that the use of the concept of ecoefficiency is capable of producing environmentally friendly products and in addition to creating a competitive advantage for the company. The method used is qualitative case study, validity of data using triangulation test for cross check between interview result, observation, and documentation with supporting theory. The analytical tools used to test the prevalence of data are data reduction, data presentation, and conclusions. This study found that the business approach used is business strategy cost leadership. In the calculation of ecoefficiency, the resulting ratio is greater than 1 , indicating that the company is efficient in production, and environmentally competitive. The results of the analysis are supported by the wastewater treatment system (IPAL) used by companies to reduce the impact of waste generated. The entire company has cleaned and environmentally friendly products with the concept of ecoefficiency in increasing the company's competitive advantage.
\end{abstract}

Keywords - ecoefficiency, competitive advantage, green product

\section{INTRODUCTION}

Today, most of the world's industries are turning to a green economy, an environmentally friendly and efficient economy in the use of natural resources. In Indonesia, people's consumptive behavior will affect the increasing needs of goods and services. Competition in the industrial world is required to gain a large profit by the use of small resources. This competition makes the business enterprise must have a competitive advantage from its competitors. The main change in the business environment is the increased customer expectations of product functionality and quality [2].

In the last twenty economic development in Indonesia leads to industrialization. There are approximately 30,000 industries operating in Indonesia from year to year has increased. The amount of industrial increase is proportional to the amount of increased pollution generated from industrial production processes [1]. DeSimone and Popoff [3] introduces the concept of ecoefficiency as an idea that is an effort to improve the efficiency of the company by minimizing the output of waste through the production process or environmental clean technology. Huppes and Ishikawa [4] provides the argument that ecoefficiency produces environmental intensity and environmental productivity in the field of value creation, and the cost of environmental improvement and environmental cost effectiveness in the area of environmental improvement actions.

Increasing ecoefficiency becomes one of the company's strategy in order to compete with competitor company and besides able to increase company's profit [5]. An action to protect the environment by a company can create a good image of the company and be able to increase sales [6]. Lay and Panjaitan [7] said that the results of the calculation of ecoefficiency is expected to be a consideration for companies to be able to begin to reduce the impact on the environment when making the existing production process. Environmental issues become important for companies to get a good image of the community [8].

Green product has a positive impact on the environment and is expected to be a competitive advantage for the company. According to Albino, Balice [9] a product is said to be a green product when, when the production process, the use of materials, disposal, and environmental and social 
performance have been integrated to create green products. The characteristics of green products are recycled goods, recyclable or reusable, efficient, environmentally friendly packaging, green labeled (labled), rentable or loanable, and certified [10]. The concept of eco efficiency meets the criteria in the manufacture of environmentally friendly products by processing the net production process based on superior product quality.

World Bussiness Council of Sustainable Development [11] states that companies implementing the concept of ecoefficiency intend for several reasons, such as record the performance and progress of the company; identify and prioritize opportunities for growth; and identify cost savings and other benefits associated with ecoefficiency. There are two contributions in this study, firstly, providing knowledge of the implementation of the concept of ecoefficiency that links between an economic and ecological point of view on a firm's business strategy. Second, to provide knowledge that in the application of this concept of ecoefficiency can increase the company's competitive advantage based on the efforts of green product.

In the next section of this paper discuss the study of research literature, the three describe the methods used in the study, the four describe the results of analysis and discussion and the last section describes the conclusions of this study.

\section{LITERATURE REVIEW}

\section{A. Environmental Accounting}

Environmental accounting is a term that seeks to group financing by companies and governments in environmental conservation into the company's environmental and business practices posts. Gale and Stokoe [12] states that financial environment accounting emphasizes the analysis and reporting of components of costs and obligations related to environmental issues. These environmental conservation activities will ultimately emerge environmental costs that must be borne by the entity.

Environmental accounting can also be analogous to a quantitative measurement framework for environmental conservation activities conducted by companies or organizations [1, 13]. Reporting environmental costs allows stakeholders to have a motivation to identify ways that reduce environmental costs to improve environmental quality.

\section{B. Ecoefficiency Concept}

Ecoefficiency is a tool used to add value to products with environmental impact reduction [7, $14,15]$. The purpose of implementing ecoefficiency include customers wanting cleaner products, ie products manufactured without damaging the environment and the use and disposal of environmentally friendly; employees prefer to work in companies that are environmentally responsible, and generate greater productivity; companies get external benefits with environmental responsibility; good environmental performance generates significant social benefits; improving environmental performance can inspire managers' desire to innovate; and reduction of environmental costs can maintain or create competitive advantage [16].

In the research Lay and Panjaitan [7] ecoefficiency brings two eco concepts of ecology and economy. That is, ecoefficiency connects the value of a product or service to the resulting environmental impact. The ecoefficiency equation as follows :

$$
\text { Ecoefficiency }=\frac{\text { Value of the product }}{\text { Cost }+ \text { Environmental cost }}
$$

In the calculation of ecoefficiency, if the resulting ratio is $>1$ (greater than 1 ) then the company can be said to have been efficient in production and environment. While the resulting ratio < 1 (less than 1 ), then the company has not been efficient in production and environment [7].

\section{Environmental Management Accounting}

Environmental management accounting is integral in corporate management. Environmental management accounting itself is the process of identifying, collecting, estimating, analyzing, reporting and transmitting information on information based on material and energy flows; information based on environmental costs; and other measurable information formed by an environmental management accountant for corporate decision-making [17]. Schaltegger and 
Burritt [18] environmental management accounting (EMA) is an environmental management and economic performance through the development and implementation of accounting systems related to the environment and its practices appropriately.

Singgih [19] states that five combinations of approaches are comprehensive: reduce and prevention for waste; demand side management; design for environment; product stewardship; and full costing accounting. Burritt, Hahn [20] integrating two environmental components namely monetary environmental management accounting and physical environmental management accounting.

\section{Relation of ecoefficiency concept, competitive advantage and green product}

Ecoefficiency helps companies, individuals, governments or organizations become more sustainable. Ecoefficiency is expected to achieve cost efficiency and environmental benefits. This environmental approach will increase competitive advantage. According to Ikhsan [21] states that the external function of environmental accounting provides the authority for the company to influence the decision-making of stakeholders, such as customers, business associates, investors, local residents as well as administrative sections. And an important factor to note is the disclosure of the results of environmental conservation activities in the form of accounting data.

Increasingly fierce business competition makes enterprise management must think hard to find the right way to survive and at the same time succeed in achieving corporate goals such as profit, market share, growth and others [22]. Porter [23] states that the main function of management is related to strategy of establishing and communicating the unique position of the company, making trade off, and trying to create conformity in various activities.

Implementation of the strategy theory put forward by Barney [24] has three competitive position of the company, namely competitive advantage, competitive parity, and competitive disadvantages. Companies that have a cost strategy in their environment indirectly have cost competitive advantage because the company has a management strategy in its environmental policy, which will have an impact in determining the cost per unit of products produced by the company. Reduced sales costs from environmental impacts will be lower than sales of product costs that do not subtract at all. It can be the company's competitive advantage based on the efforts of green product.

\section{METHOD}

\section{A. Research approach}

This research uses qualitative approach of case study. Is a research that intends to understand a case or phenomenon experienced by research subjects such as behavior, perception, motivation, action and others holistically by way of describing in the form of words and language, in a special context that is natural by utilizing various scientific methods [25].

\section{B. Data collection}

Technique of collecting data in this research is done by using method of observation, interview, and documentation [26].

\section{Test data validity}

Validity test is an effort to increase the degree of data trust [25]. In this research using triangulation test, that is using triangulation theory for cross check between interview result, observation, and documentation with supporting theory.

\section{Data analysis technique}

Technical analysis used in business approach using ecoefficiency concept in increasing competitive advantage based on green product effort that is data reduction, display data, and data conclusion drawing / verivication [27].

\section{IV.RESULT AND DISCUSSION}

\section{A. Corporate business approach}

Companies implement business strategy on one of the strategic management concepts of cost leadership, cost leadership business strategy focus to gain profit by reducing economic cost under all the competitors [24]. The result of triangulation shows that the company considers the approach to the employee for the purpose of the production activity can be achieved. The company has the power to determine the selling price, because the other competitors will not raise the selling price before the company makes a decision. 
The company provides good employee benefits to maintain product quality. In addition, the company recruit employees to the community around the company's environment. It shows that the company's business approach implements human resource management, production and marketing approaches.

\section{B. Ecoefficiency concept company}

The concept of corporate ecoefficiency is indicated by the use of production raw materials such as fresh fish, vegetables and flour. The raw materials do not cause the impact of hazardous production that can pollute the environment. In addition, the company uses Waste Water Treatment Installation (WWTP) to minimize wastewater into waste that is not harmful to the environment. In addition, the company provides training to employees to improve the competence of each employee.

The ratio of ecoefficiency is obtained from cost and sales data, this ratio is calculated by dividing net sales by total expenditure including environmental costs. Based on the calculation, the net sales value for January is Rp. 512.412.000, while the cost incurred is Rp. 399.179.981. The results of the calculation as follows:

$$
\begin{aligned}
& \text { Ecoefficiency }=\frac{\text { Value of the product }}{\text { Cost }+ \text { Environmental cost }} \\
& \text { Ecoefficiency }=\frac{\operatorname{Rp} 500.257 .000}{\operatorname{Rp} 376.440 .995+\operatorname{Rp} 22.738 .986} \\
& \text { Ecoefficiency }=1,25
\end{aligned}
$$

The result obtained is 1.25 in January, while the calculation in February is as follows:

$$
\begin{aligned}
& \text { Ecoefficiency }=\frac{\text { Value of the product }}{\operatorname{Cos}+\text { Environmental cost }} \\
& \text { Ecoefficiency }=\frac{\operatorname{Rp} 571.547 .000}{\operatorname{Rp} 387.551 .700+\operatorname{Rp} 24.849 .875} \\
& \text { Ecoefficiency }=1,39
\end{aligned}
$$

The result obtained was 1.39 in February and increased from the previous month. From the results obtained can be shown that the company is efficient in the field of production and environment.

TABLE 1.

CALCULATION OF ECOEFFICIENCY RATIO OF PT. INDO LAUTAN MAKMUR SIDOARJO FROM JANUARY TO FEBRUARY 2015

\begin{tabular}{|l|r|r|}
\hline URAIAN & January (Rp) & February (Rp) \\
\hline \multicolumn{2}{|l|}{ Cost + Environmental Cost } \\
\hline $\begin{array}{l}\text { Evvironmental } \\
\text { cost }\end{array}$ & $22.738 .986,00$ & $24.849 .875,00$ \\
\hline Cost & $376.440 .995,00$ & $387.551 .700,00$ \\
\hline Total cost & $\mathbf{3 9 9 . 1 7 9 . 9 8 1 , 0 0}$ & $\mathbf{4 1 2 . 4 0 1 . 5 7 5 , 0 0}$ \\
\hline Value of the product \\
\hline Sales & $512.412 .000,00$ & $594.813 .000,00$ \\
\hline Sales cost & $(12.155 .000,00)$ & $(23.266 .000,00)$ \\
\hline Net sales & $\mathbf{5 0 0 . 2 5 7 . 0 0 0 , 0 0}$ & $\mathbf{5 7 1 . 5 4 7 . 0 0 0 , 0 0}$ \\
\hline Ecoefficiency & $\mathbf{1 , 2 5}$ & $\mathbf{1 , 3 9}$ \\
\hline \multicolumn{2}{|l}{ Source: Processed data $(2015)$}
\end{tabular}

Source: Processed data (2015)

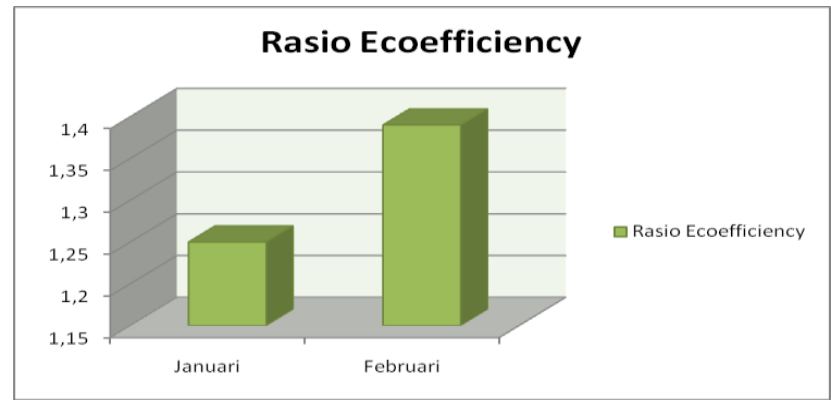

Figure 1. Comparison of ecoefficiency ratio from January to February

The ratio of ecoefficiency generated by the company in January - February is greater than 1, this indicates that the company's production process can be said both in ecology and economy because the company produces a small production cost and get high net income. The Company is able to provide customers with a clean product without any environmental damage and the use or disposal of the product is environmentally friendly. In addition, cost reduction from production and environmental processes can create or maintain competitive advantage.

Finally, using the concept of ecoefficiency the company can create environmentally friendly products and deliver more value as a competitive advantage of the company.

\section{Competitive advantage based on green product effort}

Competitive advantage based on the efforts of green product to form the public trust to the company because the products produced in accordance with the needs of today's society. In production, the company provides environmental conservation by reducing the impact of waste generated, and hence the company has a good image of the consumers. 
Companies are required to be a business unit that has unique characteristics of its competitors, uniqueness owned such as using cheap raw materials but still maintain the authenticity at the time of production; little mixed materials used; and no preservatives. The company sells products at affordable prices, this causes the company to have consumer confidence and become a company with cost leadership business strategy in its field.

The company's human resource management shows high attention to employees, and rewards every employee who has competence and achievement in work. In addition, the company provides specialized training to employees to improve their skills and increase their knowledge and understanding of the company's activities so as to create employee productivity to obtain high quality products at affordable prices. The company is still dependent on the wastewater treatment system installation which is one of the company's environmental conservation systems, but there is still a little air pollution resulting from the company and the company still strives to minimize the impact.

\section{CONCLUSIONS}

From the results of research and discussion obtained, the company shows the business strategy used is cost leadership and use the concept of ecoefficiency to enhance the company's competitive advantage through the efforts of green product. The company's business approach includes the management of natural resources, human resource management, and prevention of the impact of waste generated by the company.

The concept of ecoefficiency used by the company through the price of cheap raw materials. In addition, the raw materials used are environmentally friendly products, it is also supported by the value of the ecoefficiency ratio of the financial statements of the company shows efficient in production and environment. In addition, the company's success in achieving business sustainability is with the team's solidity within the company consisting of leaders and employees, so that the work environment created creates a kinship atmosphere that is mutually understanding and understanding.
In conclusion, the results of this study provide an explanation that the use of the concept of ecoefficiency can enhance the company's competitive advantage, in addition the company can also create products that are environmentally friendly. Michael Porter's other business strategy can certainly be a future research with the impact of applying the concept of ecoefficiency.

\section{ACKNOWLEDGMENT}

We would like to thank you for your comments and suggestions from Iman Harymawan, SE., Ph.D. and Dr. Hamidah, M.Si., Ak., CA. As a mentor who always directs and provides motivation so that this paper can be resolved properly. We also thank all the friends who always support and advise them.

\section{REFERENCES}

[1] Azizah, N., M.G.W. Endang, and M.D. A.R (2013) Analisis Penerapan Enviromental Management Accounting (Ema) Sebagai Bentuk EcoEfficiency Dalam Meningkatkan Keunggulan Kompetitif Perusahaan. Jurnal Administrasi Bisnis (JAB), 2013. 6 (2 Desember 2013).

[2] Blocher, E.J., D.E. Stout, and G. Cokins, (2010) Cost Management: A Strategic Emphasis, ed. t. ed. 1221 Avenue of the Americas, NY, 10020: McGraw-Hill.

[3] DeSimone, L.D. and F. Popoff, (2000) Eco-efficiency: the business link to sustainable development. MIT press.

[4] Huppes, G. and M. Ishikawa, (2005) Eco - efficiency and Its xs Terminology. Journal of Industrial Ecology, 9(4): p. 43-46.

[5] Kulemina, A. (2016) The impact of economic activities on the environment of the northern region. Notes, 234: p. 239

[6] Konar, A. and H.K. Cohen, (1997) Measuring Corporate Enviromental Performance: The ICI Enviromental Burden System. MIT \& Yale University.

[7] Lay, W.S. and T.W.S. (2014) Panjaitan, Menghitung Eco-efficiency di PT. APIE Indo Karunia. Jurnal Titra, Vol.2, No.2, pp. 155-160, 2014.

[8] Purwanto, (2005), Penerapan Produksi Bersih di Kawasan Industri, Seminar Penerapan Program Produksi Bersih Dalam mendorong Terciptanya Kawasan Eco-industrial di Indonesia, Jakarta,

[9] Albino, V., A. Balice, and R.M. Dangelico, (2009) Environmental strategies and green product development: an overview on sustainability - driven companies. Business strategy and the environment. 18(2): p. 83-96.

[10] Fan, H. and L. Zeng, (2011) Implementation of Green Marketing Strategy in China: A Study of the Green Food Industry.

[11] WBCSD, (2000) Measuring Eco-Efficiency: A Guide to Reporting Company Performance.

[12] Gale, R.J.P. and P.K. Stokoe, (2001) Environmental cost accounting and business strategy, in chris madu (Ed). Handbook of environmentally conscious manufacturing, : p. Victoria: Kluwer Academic Publisher.

[13] Suartana, I.W., (2010) Akuntansi Lingkungan Dan Triple Bottom Line Accounting: Paradigma Baru Akuntansi Bernilai Tambah. Jurnal Bumi Lestari, Volume 10 No. 1, hlm. 105 - 112, 2010. 10(1): p. 105 - 112.

[14] Müller, K. and A. Sturm, (2001) Standardized eco-efficiency indicators. Ellipson AG., Basel, Switzerland.

[15] Hur, T., S. Lim, and H. Lee, (2003) A study on the eco-efficiencies for recycling methods of plastics wastes. InLCA. 22.

[16] Mustikaningrum, S., (2012) Pendekatan Bisnis Dengan Menggunakan Konsep Ecoefficiency terhadap Cost Reduction Studi Kasus PT Petrokimia Gresik, in Fakultas Ekonomi dan Bisnis. Universitas Airlangga Surabaya: Surabaya.

[17] Ikhsan, A., (2008) Akuntansi Lingkungan dan Pengungkapannya. Yogyakarta: Graha Ilmu. 
[18] Schaltegger, S. and R. Burritt, (2000) Contemporary environmental accounting: issues, concepts and practice.: Greenleaf Publishing.

[19] Singgih, M.L., (2006) Pengukuran dampak lingkungan menggunakan environmental management accounting (EMA).

[20] Burritt, R.L., T. Hahn, and S. Schaltegger, (2002). Towards a comprehensive framework for environmental management accounting-Links between business actors and environmental management accounting tools. Australian Accounting Review. 12(27): p. 39-50.

[21] Ikhsan, A., (2009) Akuntansi Manajemen Lingkungan. Yogayakarta: Graha Ilmu.

[22] Aisyah, M.N., (2007) Peran strategi, sumber daya serta perubahan teknologi dan lingkungan terhadap penciptaan keunggulan kompetitif yang berkesinambungan. Jurnal Ekonomi dan Pendidikan. 4(1): p. 89100.

[23] Porter, M.E., (1996) What is Strategy? Harvard Business Review. 74(6): p. 61-78.

[24] Barney, J.B., (2011) Gaining and Sustaining Competitive Advantage, ed. F. Edition, Upper Saddle River, New Jersey 07458: Pearson Education, Inc.

[25] Moleong, L.J., (2004) Metodologi Penelitian Kualitatif., Bandung: PT. Remaja Rosdakarya.

[26] Sugiyono, P.D., (2013) Metode Penelitian Kuantitatif, Kualitatif dan R\&D. Bandung: Alfabeta CV.

[27] Neuman, W.L., (2011) Social Research Methods: Qualitative and Quantitative Approaches, ed. $7^{\text {th }}, 75$ Arlington Street, Suite 300, Boston, MA 02116: Peaarson Education, Inc., 